\title{
Prognostic value of estimating serum proteins in cases of ulcerative colitis in remission
}

\author{
F. T. de DOMBAL
}

From the Colitis Clinic and the University Department of Surgery, The General Infirmary, Leeds

Recent large scale surveys carried out in Oxford and Leeds (Edwards and Truelove, 1963; Watts, de Dombal, Watkinson, and Goligher, 1966a,b) have enabled the course and prognosis of ulcerative colitis to be analysed with some degree of statistical precision in large groups of patients. However, despite these detailed large scale surveys, the individual patient's prognosis remained notoriously difficult to predict by any statistical or actuarial methods.

Further studies in a number of patients suffering from ulcerative colitis have suggested that careful electrophoretic analysis of the serum proteins may be of some use during severe attacks of colitis, for such studies may enable the outcome of each individual severe attack to be forecast at an early stage (de Dombal, 1967a,b; de Dombal, 1968a). The present paper deals with 110 outpatients seen during 1966 at a time when the disease was relatively quiescent; and examines the effect of the various serum protein levels upon their subsequent prognosis.

\section{CLINICAL MATERIAL AND METHODS}

Between 1 January 1966 and 31 March 1967, samples of blood were removed from 110 patients known to be suffering from ulcerative colitis, who attended the colitis clinic of the University Department of Surgery at the General Infirmary at Leeds. Ulcerative colitis was diagnosed in each patient during life on the basis of characteristic symptoms, sigmoidoscopic appearances, and radiological studies. In those of the group of patients who eventually came to surgery, the diagnosis of ulcerative colitis was later substantiated by histopathological examination of the excised specimen. The mean age of this group of patients was 37.8 years, the group being comprised of 49 males and 61 female patients.

During the course of each outpatient's regular clinical review, a sample of 5 to $10 \mathrm{ml}$ of blood was removed from an arm vein for analysis. Normally only one sample was removed from each patient; though a smaller group of patients provided regular samples of 5 to $10 \mathrm{ml}$ of blood at weekly or two-weekly intervals over a period of some months. In all just under 300 samples of blood were removed for analysis from the 110 patients.

The technique of analysis of the serum proteins has essentially been that described by Kohn (1960). The serum was separated immediately by centrifugation. Electrophoresis was performed usually within two or three hours of withdrawal of the blood sample, and in every case, within 48 hours of withdrawal, the serum being stored frozen meanwhile at a temperature of $-4^{\circ} \mathrm{C}$.

Electrophoresis was carried out in a horizontal tank using a standard barbitone buffer. Strips of cellulose acetate membrane were initially impregnated with veronal buffer at $p \mathrm{H} 8 \cdot 6$. After impregnation the strips were placed across the shoulders of a Shandon horizontal electrophoresis tank, the polarity of which was reversed after every run. Serum was applied to each strip approximately 3 to $5 \mathrm{~cm}$ from the cathode end, and the strip then run for 100 minutes or thereabouts at a constant current of 0.5 amps per centimetre strip width using a Vokam power pack.

After electrophoresis each strip was immediately immersed in dye solution $(0.5 \%$ light green in $2.5 \%$ trichloracetic acid) and left overnight for approximately 20 hours. Subsequently the strips were washed in $2.5 \%$ trichloracetic acid until the wash solution was colourless, and allowed to dry. (If urgently required strips can be dried between sheets of blotting paper in a gently heated press, but this is neither standard nor optimal procedure.)

When perfectly dry the strips were thoroughly impregnated with Whitemor 120 transparency oil. A $1 \mathrm{~cm}$ band down the centre of each strip was selected by masking out the rest of the strip; and this $1 \mathrm{~cm}$ band scanned using an EEL scanner, readings being taken at intervals of $1 / 40$ th of an inch along the strip.

The relative and absolute values of each protein fraction were then calculated in the usual way, absolute values being obtainable only if concomitant biuret studies had been performed. (If preferred, the process of scanning and calculation of the area under each peak of the curve may be performed automatically using devices such as the Chromoscan fitted with an automatic integrator.)

There is as yet unfortunately no means of universally standardizing individual electrophoretic techniques. Samples were therefore initially removed from 38 healthy volunteers to determine the normal value and pattern for this particular technique and staining method. The control samples were treated in exactly the same way as the samples from the patients with ulcerative colitis.

Each specimen of serum was divided into two, and 
entirely separate investigations were performed on each of the two samples, the results being ultimately expressed as a mean of the two estimations. On rare occasions where these two estimations differed markedly the results were discarded and a fresh sample was obtained.

\section{FINDINGS}

The protein levels which were noted in the 38 healthy volunteers (Table I) differ little from those noted in healthy blood donors by Kohn (1960) and by Soergel and Ingelfinger (1961); although the albumin level in the present group of normal subjects was slightly lower than that reported in these other two studies. Table I also confirms the findings of Soergel and Ingelfinger (1961), that when compared with the normal subjects there is generally a slight fall in the colitic outpatients' serum albumin level and a rather more prominent rise in the alpha 2 and beta globulin levels. Finally, Table I shows that there was practically no difference in the serum gamma globulin levels between the normal subjects and the colitis outpatient group.

\section{TABLE I}

COMPARISON OF SERUM PROTEIN LEVELS IN 38 NORMAL SUBJECTS AND 110 COLITIC OUTPATIENTS

\begin{tabular}{lrrl} 
& $\begin{array}{l}\text { Normal } \\
\text { Subjects }\end{array}$ & $\begin{array}{l}\text { Colitic } \\
\text { Outpatients }\end{array}$ & $\begin{array}{l}\text { Significance } \\
\text { of Difference }\end{array}$ \\
\hline Albumin & $55.1^{1} \pm 1.4$ & $50.9 \pm 0.9$ & P $>0.1$ \\
Alpha 1 globulin & $2.5 \pm 0.2$ & $3.2 \pm 0.2$ & $\mathbf{P}>0.2$ \\
Alpha 2 globulin & $9.7 \pm 0.1$ & $11.6 \pm 0.3$ & $\mathbf{P}<0.02$ \\
Beta globulin & $13.0 \pm 0.3$ & $14.8 \pm 0.3$ & $\mathbf{P}<0.02$ \\
Gamma globulin & $20.3 \pm 0.7$ & $19.8 \pm 0.5$ & $\mathbf{P}>0.5$
\end{tabular}

${ }^{1}$ Results expressed as percentages of total protein. Figures in each instance indicate mean values \pm standard error.

RELATIONSHIP OF SERUM PROTEINS TO SUBSEQUENT FOLLOW UP After removal of a $5 \mathrm{ml}$ blood sample for analysis each colitic patient was then followed up for a period of three months; and it was noted whether or not a further relapse of colitis occurred during that period of time. Unfortunately many of the 110 outpatients could not be dealt with in this way; for at the time of their blood sampling they either had mild, active colitis (11 patients), or suffered from incidental disease such as bronchitis or influenza (17 patients). Both of these conditions are known to cause abnormalities of the serum proteins on their own account; and hence all 28 patients in these two groups were excluded from any subsequent follow-up studies.

The correlation between serum protein levels and subsequent course of disease in the remaining 82 healthy patients is shown in Table II. This group of patients is further subdivided according to whether they spent the subsequent three months in full clinical remission (56 cases), or whether during that time they suffered a further relapse of their ulcerative colitis ( 26 cases). It can be seen that in many instances there is little difference between the two groups in respect of the various serum protein fractions; and in view of previous studies concerning the prognostic value of the gamma globulin fraction during severe attacks (de Dombal, 1967a, 1968a), it was particularly disappointing to note that this fraction appeared to exert no influence upon the subsequent prognosis of outpatients in remission.

\section{TABLE II}

SERUM PROTEIN LEVELS IN 82 PATIENTS WITH ULCERATIVE COLITIS IN FULL REMISSION AND FREE FROM INCIDENTAL DISEASE SHOWING RELATIONSHIP BETWEEN SERUM PROTEIN LEVELS AND COURSE OF COLITIS DURING ENSUING THREE MONTHS

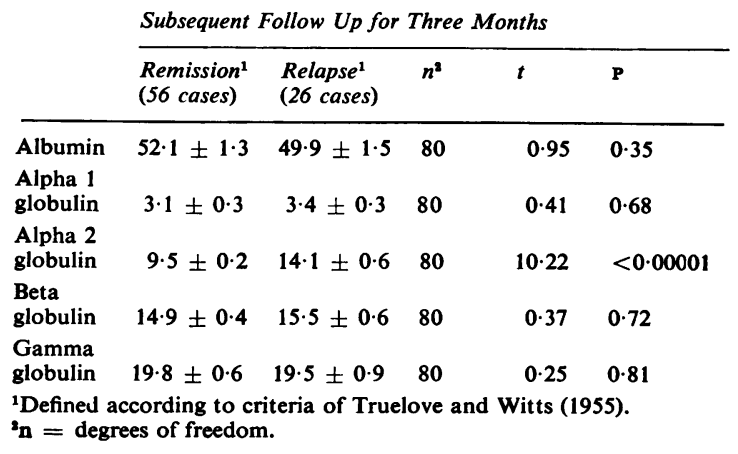

However, Table II shows that there is a considerable difference between the two groups in respect of the alpha 2 globulin fraction. Patients who subsequently spent their three months' period of follow up in full clinical remission had a mean alpha 2 globulin level of $9.5 \%$ whereas the comparable level of alpha 2 globulins in those destined to suffer a further relapse in the ensuing three months was $14.1 \%$. The difference between these two levels is highly significant statistically $(P<0.00001)$.

PROGNOSIS IN INDIVIDUAL PATIENTS It has already been emphasized that group prognosis of the kind outlined above is of relatively little value unless this can be shown to hold good for each individual patient. In this instance (Fig. 1) there is indeed a reasonably close correlation between the individual patient's serum alpha 2 globulin level and his subsequent chance of relapse during the ensuing three months. Once patients with mild active colitis or with incidental disease are excluded from consideration, it seems not unfair to assert that the 


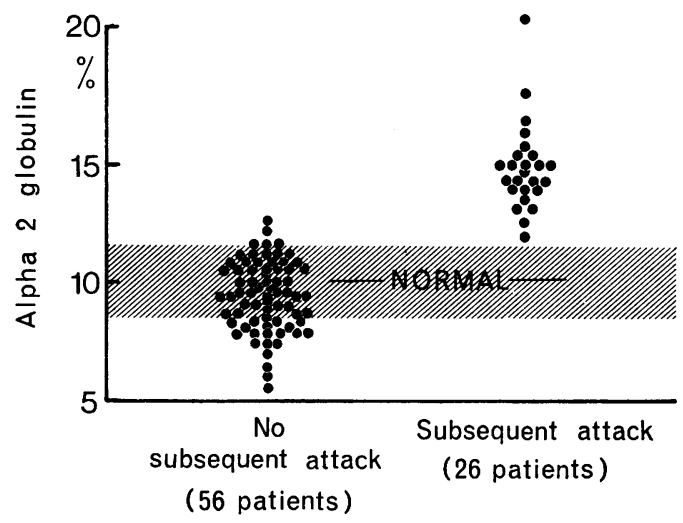

3 months follow up

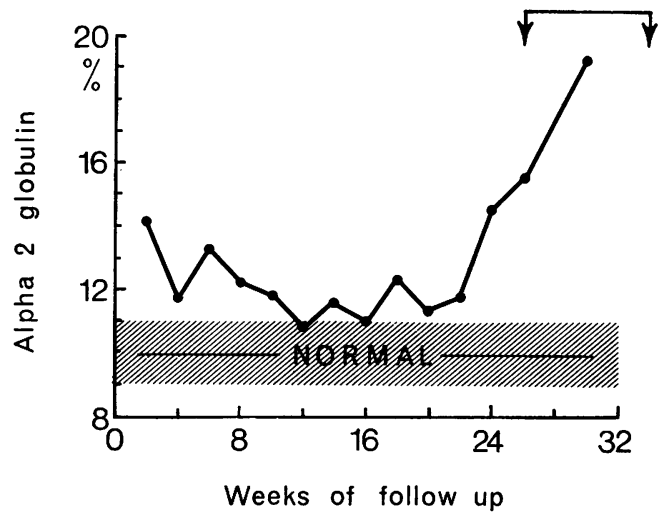

FIG. 2 .

FIG. 1.

FIG. 1. Relationship between 82 individual patients' serum alpha 2 globulin levels and their subsequent chance of relapse, excluding 28 patients with mild active colitis or incidental disease.

FIG. 2. Serial alpha 2 globulin levels in patient M.F. over a period of nine months. Note that a rise in alpha 2 globulins precedes the clinical onset of relapse.

finding of a normal alpha 2 globulin level confers a good prognosis whereas the finding of a raised alpha 2 globulin level suggests that the patient may suffer a further attack of ulcerative colitis in the near future.

It should incidentally be emphasized that these two groups of patients were, at the time of blood sampling, indistinguishable from one another in terms of age, sex, general health, extent of disease, or sigmoidoscopic appearances.

It should also be emphasized at this stage that the findings in each patient of the serum protein investigations were on each occasion merely documented and filed for future reference. Neither the patient, nor those responsible for his clinical management, were aware of the findings, until many months after each individual sample was taken.

SERIAL STUDIES Clearly, it would be impracticable to describe within the confines of this communication some 80 or more individual case histories; and indeed many cases were not followed by means of serial studies. Attention will therefore be confined to the following three typical and interesting cases.

Case 1 A young man of 23 was first seen in the concluding stages of a severe acute attack which began at the end of 1965. Subsequently his progress was followed by a regular sampling of the serum proteins over the next nine months (Fig. 2). Initially the alpha 2 globulin level descended to the top limit of normal and remained there for a period of some months. However, during August and September 1966, it gradually rose to well above the normal level; till finally, some 30 weeks after the beginning of the study, he suffered a further severe attack of ulcerative colitis, during the course of which he eventually came to surgery.

It is noteworthy that although this individual patient remained symptom-free until the sudden onset of severe symptoms 30 weeks after the commencement of the study, a steady rise in the serum alpha 2 globulin levels preceded the onset of severe clinical symptoms by a period of some six to eight weeks.

Cases 2 and 3 Comparison of two further patients (J.D. and D.M.) also illustrates this point. Both were young women aged 16 and 18 respectively. Both were first seen when in full clinical remission. A glance at Fig. 3 shows that their subsequent serum levels of alpha 2

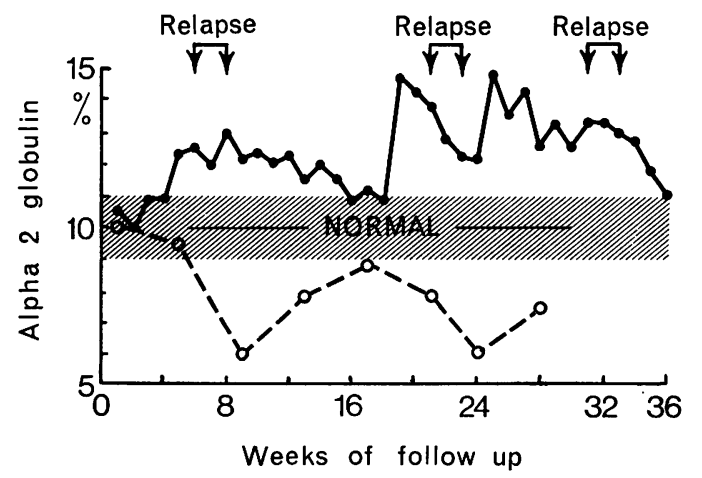

FIG. 3. Serial alpha 2 globulin levels in patients J.D. and D.M. Note that three separate clinical relapses (D.M.) were each preceded by high alpha 2 globulin levels. 
globulin differed markedly, and so did their prognosis. During the ensuing months one patient (J.D.) suffered no fewer than three definite relapses; the other patient (D.M.) remained symptom-free throughout the period of study. It can be seen from Fig. 3 that each of the acute relapses suffered by J.D. was preceded by a rise in the alpha 2 globulin level, and indeed the difference between the patients in this respect could not be more marked.

\section{DISCUSSION}

The idea that there may be some sort of correlation between serum protein patterns and the progress of disease is far from new. Neumayer, Perger, Schinko, and Tschabitscher (1956) performed 1,400 electrophoretic determinations of the serum proteins in patients suffering from multiple sclerosis, and concluded that 'these changes could be used as a basis for prognosis', although they were able to produce little concrete evidence to show that this was the case. Similarly Cooke, Fowler, Cox, Gaddie, and Meynell (1958) found a fairly close correlation between raised levels of seromucoid and active disease in the case of both regional ileitis and ulcerative colitis. Bicks, Kirsner, and Palmer (1959) even attempted to evaluate electrophoretic patterns in colitic patients, although most of their attention was confined to the gamma globulin fraction, and the criteria used to evaluate their clinical data were far from precise.

Others, however, have asserted with equal conviction that the serum protein levels cannot be used as a basis for prognosis. Jager, Brown, and Nickerson (1951) warned that the various electrophoretic changes noted may be the effect of therapy rather than any change in the patient's underlying disease whereas Ohlagen (1957), studying rheumatoid arthritis, claimed that the various protein levels (especially the gamma globulin level) gave no indication of the severity of the disease process whatsoever.

Previous studies of the serum proteins in severely ill ulcerative colitis patients (de Dombal, 1967a,b; de Dombal, 1968) have indicated that the views of Neumayer et al (1956), Cooke et al (1958), and Bicks and his colleagues (1959) are probably correct where severe active disease is concerned. In the present study the further prognostic problems of the relatively fit patient in clinical remission are investigated.

EXPRESSION OF RESULTS There has been considerable debate during the last 10 years as to whether the results of serum protein electrophoresis should be expressed in relative terms, $i e$, as a fraction of the total protein level, or as an absolute value (in $\mathrm{g} \%$ ). Jencks (1955) and Bicks (1961) claim that any results are best expressed as percentage values of total protein, thus avoiding the additional errors involved in estimating total protein and total albumin values. By contrast Soergel and Ingelfinger (1961) and Kohn (1967) maintain that values should be expressed as $\mathrm{g} \%$, for it is otherwise impossible to determine whether electrophoretic changes are absolute or merely relative.

In a sense both of these views are correct, for results in the present series of patients (de Dombal, 1968a) confirm the impression of Soergel and Ingelfinger (1961) that there is an excellent correlation between these two methods of expressing electrophoretic results, at least in colitic patients. It seems therefore that the method of choice for expression of results is that which is the more simple and the more accurate of the two, namely, expression of results in relative terms as percentage values of the total protein present. This is the method which is adopted in the present study.

gamma GLobulins A major disappointment in the present study has been the failure to base any sort of worthwhile prognosis upon the gamma globulin levels in the patients' sera. In view of the extreme usefulness of gamma globulin estimations in determining the outlook in severe attacks of ulcerative colitis (de Dombal, 1968a) it might have been anticipated that a similar state of affairs obtained during remission. Unfortunately this has not been the case, the gamma globulin levels being almost identical $(19.8 \% \mathrm{vs}, 19.5 \%)$ in the two groups of patients who did or did not suffer a further attack during the ensuing three month period. Reluctantly, therefore, it must be accepted that Ohlagen's (1957) prediction concerning the lack of value of gamma globulin estimations in remission holds good for the present series of patients.

ALPHA 2 GLOBULINS By contrast, the findings concerning the alpha 2 globulin fraction are of considerable interest. The mean level of alpha 2 globulin in the 56 patients destined to spend their ensuing three months in remission $(9.5 \%$ ) differs significantly from the mean level $(14.1 \%)$ in the 26 patients who suffered a further attack during that time $(t=10 \cdot 22$, $\mathrm{n}=80, \mathrm{P}<0.00001)$. Moreover, Fig. 1 shows that the same findings hold good in the individual patient, with only a very few exceptions. These conclusions are reinforced by the serial studies conducted in certain of the patients; these again indicate (Figs. 2 and 3) that many acute attacks of ulcerative colitis are preceded by a rise in the serum alpha 2 globulin level which is detectable 
at a point in time when the patient is still in clinical remission of symptoms.

CLINICAL IMPLICATIONS It seems therefore that in a substantial number of patients attacks of ulcerative colitis can be forecast with some degree of accuracy before they become clinically apparent. However, to this important conclusion several qualifications must be attached.

First there is the problem of coincidental disease. In fully one quarter of the present group of 110 patients mild colitic symptoms or other coincidental diseases such as influenza or bronchitis, or even in one patient tooth extraction (Fig. 4), invalidated the results. This is most certainly a serious drawback in that meaningful results cannot be obtained from almost one in three outpatients suffering from ulcerative colitis; and it is difficult to see how this problem may be overcome other than by meticulous questioning of the outpatients concerned. Of course, this does not mean that this prognostic index is wrong in such patients, but merely that the test is inapplicable in this group. Nonetheless, this in itself constitutes a formidable problem.

Second, the difference between the two groups of patients' alpha 2 globulin levels is not as great as it may appear at first sight. It is technically a relatively simple matter to distinguish between $10 \%$ of the total protein and $16 \%$ but to distinguish between $12 \%$ and $14 \%$ may be extremely difficult. Thus inevitably, there is a small group of patients in an intermediate category, in whom it is impossible to be sure whether they will have further relapses or not.

This problem can be minimized by scrupulous and meticulous attention to the details of electrophoretic technique, along the lines set out previously but this in itself is something of a disadvantage, for

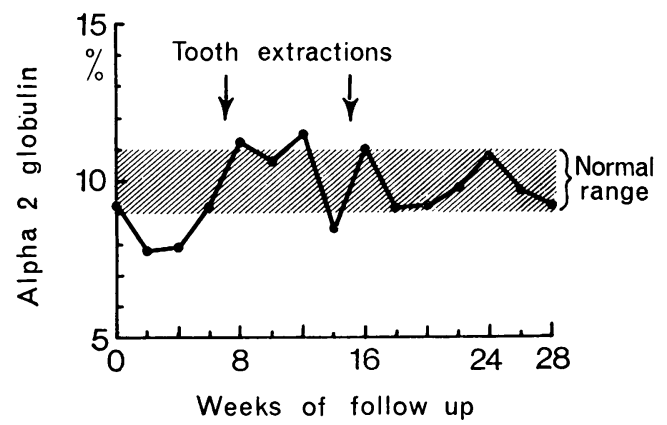

FIG. 4. Serial alpha 2 globulin studes in control patient S.M.M.Q. This patient did not have colitis. Note rise in alpha 2 levels produced by incidental trauma (tooth extraction). it impairs the convenience of this investigation as a routine clinical procedure. It may well be that the problem will only fully be solved when quantitative immunophoretic studies indicate which of the many alpha 2 globulin fractions are most closely connected with the approaching onset of a further clinical relapse of colitis. Such studies are now under way (de Dombal, 1969) but clearly the collation of sufficient data will be a lengthy task.

Nevertheless, despite all these present imperfections, it seems that where a firm prediction can be made in the individual patient, this prediction will be at least $90 \%$ accurate; and this one fact alone opens up further therapeutic possibilities. Quite apart from the social and occupational convenience of such information, eg, for a patient contemplating a long business trip or foreign holiday, there remains the possibility of treating attacks of ulcerative colitis before they become clinically apparent. Initial results in a very few patients suggest that some attacks may indeed be preventable in this way (de Dombal, 1968b) but once again the collation of sufficient data for accurate statistical evaluation will be a matter of time. Moreover, the most stringent controls and safeguards will be required before such an important inference can be drawn with any degree of certainty.

AETIOLOGICAL IMPLICATIONS The role of the alpha 2 globulins in the aetiology and pathogenesis of a number of diseases has been closely studied in recent years, for it is well known that this fraction of the serum proteins is raised in a number of other diseases, both inflammatory and neoplastic (HochLigetti, Irvine, and Spinkle, 1953; Neumayer et al, 1956; Cooke et al, 1958; Peterman, 1960; Heim and Lane, 1964; Atwell, Duthie, and Goligher, 1965; McCathie, Owen, and Macpherson, 1966).

Indeed it has even been suggested that this rise in the alpha 2 globulin level may in some way be responsible for the disease in the colon. Burch and Burwell (1965) asserted that in many autoimmune diseases, where the target organ is situated behind a blood tissue barrier, humoral autoantibodies migrating on electrophoresis with the alpha 2 globulin fraction may be responsible for exacerbations of the illness although they were unable to produce any concrete serological evidence to support this intriguing hypothesis.

Unfortunately, the present series of studies has done little to resolve this most difficult problem. Certainly it is interesting to record that many clinical attacks of ulcerative colitis seem to be preceded by a rise in the alpha 2 globulin fraction and this finding accords remarkably well with the predictions of Burch and Burwell (1965). On the 
other hand, it is impossible to be certain that the observed changes are not merely the result of a 'subclinical' phase, preceding the main clinical attack. Indeed the finding of an elevated alpha 2 level in the venous drainage of the inflamed colon (de Dombal, 1967b) would seem to support this latter hypothesis.

It is difficult to see how this aetiological problem can be resolved using the present methods of study, although if reliable quantitative immunophoresis becomes available (see de Dombal, 1969), further elucidation may be possible.

\section{SUMMARY}

Electrophoresis of the serum proteins has been performed in 110 patients suffering from mild or inactive ulcerative colitis, and the electrophoretic pattern of each patient's protein correlated with the subsequent prognosis during the next three months.

In 28 of the 110 patients, meaningful evaluation of the serum proteins in terms of prognosis was not possible either because they suffered from mild colitis symptoms (11 patients) or because they suffered from unrelated coincidental disease at the time of their blood sample (17 patients).

The remaining patients were divided into two groups according to whether or not they suffered a further relapse during the three month follow-up period. All 26 patients who suffered a subsequent relapse were found to have a raised alpha 2 globulin level at the time of their blood sample. By contrast, only three of the 56 patients who remained in remission during the ensuing three months showed a raised alpha 2 globulin level.

Serial studies in a number of patients confirmed that attacks of ulcerative colitis are often preceded by a rise in the alpha 2 globulin level before the onset of clinical symptoms.

The clinical and aetiological implications of these findings are discussed.

\section{ADDENDUM}

Since these investigations were carried out, other studies (Dearing et al, 1969) concerning the $\alpha 1$, glycoproteins have also noted their reliability as an index of the severity of disease.

I am grateful to Professor J. C. Goligher for his helpful advice and encouragement, and for permission to study patients under his care. It is also a pleasure to acknow- ledge the encouragement and advice of Dr P. R. J. Burch and Professor R. G. Burwell, whose intriguing aetiological hypothesis provided much of the initial impetus for this series of serological studies. Finally I am indebted to Mrs Rita Bulmer for her valuable technical assistance.

\section{REFERENCES}

Atwell, J. D., Duthie, H. L., and Goligher, J. C. (1965). The outcome of Crohn's disease. Brit. J. Surg., 52, 966-972.

Bicks, R. O. (1961). In disc sssion to Soergel and Ingelfinger. Gastroenterology, 40, 45-46.

_-, Kirsner, J. B., and Palmer, W. L. (1959). Serum proteins in ulcerative colitis. I. Electrophoretic patterns in active disease. Ibid., 37, 256-262.

Burch, P. R. J., and Burwell, R. G (1965). Self and not-self: a clonal induction approach to immunology. Quart. Rev. Biol., 40, 252-279.

Cooke, W. T., Fowler, D. I., Cox, E. V., Gaddie, R., and Meynell, M. J. (1958). The clinical significance of seromucoids in regional ileit is and ulcerative colitis. Gastroenterology, 34, 910-919.

Dearing, W. H., McGuckin, W. F., Elveback, L. R. (1969). Serum $\alpha$, -acid glycoprotein in chronic ulcerative colitis. Gastroenterology, 56, 295-303.

De Dombal, F. T. (1967a). The prognostic value of serum proteins in ulcerative colitis. Brit. J. Surg., 54, 857-859.

- (1967). Serum proteins in ulcerative colitis: electrophoretic patterns in the inferior mesenteric artery and vein. Gut, 8, 482-485.

- (1968a). Prognostic value of the serum proteins during severe at tacks of ulcerative colitis. Ibid., 9, 144-149.

- (1968b). Unpublished observations.

(1969). Quantitative immunophoretic studies in ulcerative colitis. In preparation.

Edwards, F. C., and Truelove, S. C. (1963). The course and prognosis of ulcerative colitis. Parts I and II. Gut, 4, 299-315.

Heim, W. G., and Lane, P. H. (1964). Appearance of slow alpha 2globulin during the inflammatory response of the rat. Nature (Lond.), 203, 1077-1078.

Hoch-Ligeti, C., Irvine, K., and Sprinkle, E. P. (1953). Investigation of serum protein patterns in patients undergoing operation. Proc. Soc. exp. Biol. (N.Y.), 84, 707-710.

Jager, B. V., Brown, H., and Nickerson, M. (1951). Alterations in plasma proteins, plasma volume, and volume of packed red cells in patients receiving ACTH or cortisone. J. Lab. clin. Med., 37, 431-443.

Jencks, W. P., Jetton, M. R., and Durrum, E. L. (1955). Paper electrophoresis as a quantitative method: serum proteins. Biochem. J., 60, 205-215.

Kohn, J. (1968). Cellulose acetate electrophoresis and immunodiffusion techniques. In Chromatographic and Electrophoretic Techniques. vol. II, Zone electrophoresis, edited by I. Smith, p. 84. Heinemann, London.

McCathie, M., Owen, J. A., and Macpherson, A. I. S. (1966). The effect of surgery on levels of some plasma proteins. Scot. med. J., 11, 83-88.

Neumayer, E., Perger, F., Schinko, H., and Tschabitscher, H. (1956). Das Serumeiweissbild bei der multiplen Sklerose. Wien. Z. Nervenheilk., 13, 46-64.

Olhagen, B. (1957). Electrophoretic blood protein analysis in rheumatoid arthritis and other collagen diseases. (Abstract.) Ann. rheum. Dis., 16, 387-388.

Petermann, M. L. (1960). Alterations in plasma protein patterns in disease. In The Plasma Proteins, edited by F. W. Putnam, vol. 2. Academic Press, New York.

Soergel, K. H., and Ingelfinger, F. J. (1961). Proteins in serum and rectal mucus of patients with ulcerative colitis. Gastroenterology, 40, 37-46.

Watts, J.McK., De Dombal, F. T., Watkinson, G., and Goligher, J.C. (1966a). Early course of ulcerative colitis. Gut, 7, 16-31.

$-,, \ldots, 1,1966 \mathrm{~b})$. Long-term prognosis of ulcerative

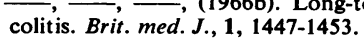

